\title{
Effects of additional electrical stimulation and pre-rigor conditioning temperature on the ageing potential of hot-boned bovine muscles
}

\author{
Prabhu Balan ${ }^{1, *}$, Mustafa M. Farouk², Maryann Staincliffe ${ }^{2}$, Adam D Stuart $^{2}$, \\ Robert Kemp ${ }^{2}$, and Cameron Craigie ${ }^{2}$
}

\begin{abstract}
* Corresponding Author: Prabhu Balan Tel: +64-69517943, Fax: +64-63505655, E-mail: p.balan@massey.ac.nz
\end{abstract}

'Alpha-Massey Natural Nutraceutical Research Centre, Riddet Institute, Massey University, Private Bag 11

222, Palmerston North 4442, New Zealand

${ }^{2}$ AgResearch Ltd, Ruakura Research Centre, Hamilton 3214, New Zealand

ORCID

Prabhu Balan

https://orcid.org/0000-0003-0540-1471

Mustafa M. Farouk

https://orcid.org/0000-0001-6089-1640

Maryann Staincliffe

https://orcid.org/0000-0002-8380-0235

Adam D Stuart

https://orcid.org/0000-0001-7700-8316

Robert Kemp

https://orcid.org/0000-0003-3525-4898

Cameron Craigie

https://orcid.org/0000-0002-0396-7490

Submitted Oct 10, 2019; Revised Nov 6, 2019; Accepted Nov 17, 2019
Objective: The aim of this study is to characterize the impact of additional electrical stimulation (AES) and various pre-rigor holding temperatures (for $3 \mathrm{~h}$ ) on the ageing-potential of hot boned bovine $M$. longissimus lumborum $(L L)$.

Methods: Paired $L L$ loins from 12 bulls were hot-boned within $40 \mathrm{~min}$ of slaughter, immediate AES applied and subjected to various holding temperatures $\left(5^{\circ} \mathrm{C}, 15^{\circ} \mathrm{C}, 25^{\circ} \mathrm{C}\right.$, and $\left.35^{\circ} \mathrm{C}\right)$ for $3 \mathrm{~h}$.

Results: AES did not accelerate the rate of rigor attainment, but the $3 \mathrm{~h}$ pre-rigor holding temperature did. Shear force values decreased as the pre-rigor holding temperatures increased. $\mathrm{AES}$ and holding for $3 \mathrm{~h}\left(\right.$ at $\left.25^{\circ} \mathrm{C}\right)$ resulted in higher water-holding capacity.

Conclusion: Data confirmed that AES did not influence the various meat quality parameters in the present study, but pre-rigor holding temperature $\left(25^{\circ} \mathrm{C}\right)$ alone or in combination with AES resulted in superior meat quality.

Keywords: Beef; Additional Electrical Stimulation; Meat Quality; Pre-rigor Holding Temperature; Shear Force; Water-holding Capacity

\section{INTRODUCTION}

The red meat industry identified that improving the eating quality of beef as essential in meeting the fast-growing demands for high value beef products in discerning and highly competitive international markets [1]. It is particularly important that the industry reduce the inconsistent tenderness of beef being contributed by the so-called 'intermediate $\mathrm{pHu}$ bull beef [2].

The ultimate $\mathrm{pH}$ of meat ( $\mathrm{pHu}$ ) has a considerable impact on meat quality [3]. Normal $\mathrm{pHu}$ samples are a bright red color that consumer's associate with good quality and the meat tenderizes with ageing. High pHu meat results in tender but dark, firm and dry (DFD) product. In contrast to high and low $\mathrm{pHu}$ meat, the tenderness of intermediate $\mathrm{pHu}$ meat is much more inconsistent and consequently it is of poorer quality. A significant proportion of bull beef can be categorized as intermediate $\mathrm{pHu}(18 \%)$ and seasonal variation may also add to the inconsistency [4]. The underlying biochemical mechanisms related to this inconsistent tenderness issue are not fully understood. Therefore, improving the meat quality through novel meat processing systems for these classes of carcasses needs to be developed.

Varying pre-rigor environments generated by the application of electrical stimulation (ES) and/or pre-rigor chilling conditions influence the rate of glycolysis and subsequent $\mathrm{pH}$ decline in muscles post mortem. One of the major post mortem interventions implemented 
by the meat industry for enhancing meat quality attributes is carcass ES [5]. There are discrepancies among various reports on the influence of ES on meat quality. Some authors found positive effects due to ES [6,7], while others found no effects [8] and others reported negative effects [9]. Despite the differences, ES has been shown to enhance tenderness due to reduction in muscle ATP [5]. The complex interaction of $\mathrm{pH}$ and temperature decline in pre-rigor muscle has a significant role in meat tenderisation by influencing proteolytic enzyme activity, particularly $\mu$-calpain [6]. The meat industry typically refers to this as the "pH/temperature window" as hot or cold shortening can result from over stimulation or high chilling rate before the $\mathrm{pH}$ has declined sufficiently. Optimal tenderness was evident when glycolysis had proceeded at an intermediate rate resulting in $6.1 \mathrm{pH}$ at $3 \mathrm{~h}$ post mortem [10].

Recently, Balan et al [6] demonstrated that various prerigor holding temperatures (especially $25^{\circ} \mathrm{C}$ or $35^{\circ} \mathrm{C}$ ) along with accelerated $\mathrm{pH}$ decline rates by low voltage electric stimulation (LVES) can have positive effects on bull M. longissimus lumborum. The treatments resulted in improved tenderness, reduced cook loss and increased sarcomere length. Furthermore, the treatments positively influenced the myofibrillar proteins and small heat shock proteins (sHSP) activities associated with $\mu$-calpain activity in bull beef samples. LVES combined with the $3 \mathrm{~h}$ pre-rigor holding temperature (for ES-25 and ES-35 samples) resulted in no cold shortening (or heat induced shortening) even though the samples were aged at $1^{\circ} \mathrm{C}$. Based on the above findings [6], it can be implied that there is an optimal condition (i.e. combination of LVES with $3 \mathrm{~h}$ pre-rigor holding temperature at $25^{\circ} \mathrm{C}$ or $35^{\circ} \mathrm{C}$ ) for maximizing the ageing-potential for bull beef. Moreover, the results discussed above [6] from bulls which were stunned by captive bolt (carried out to avoid any electrical effects before stimulation), need to be verified (in all the three ranges of $\mathrm{pHu}$ ) using current slaughter practices where the animals are electrical stunned and immobilized pre-slaughter.

We hypothesize that the additional electric stimulation (AES), pre-rigor $\mathrm{pH}$, and temperature decline will positively influence the ageing-potential of hot boned bull beef muscle, particularly from intermediate $\mathrm{pHu}$ carcasses. Therefore, the objective of this study is to characterize the impact of AES and various pre-rigor holding temperatures (for $3 \mathrm{~h}$ ) on the ageingpotential of hot boned bull beef muscle.

\section{MATERIALS AND METHODS}

\section{Raw materials and processing}

A total of 12 cattle (around 24-month-old bulls) were slaughtered at a New Zealand meat plant over three slaughter days. Bulls in this study were electrically stunned for Halal kill (frequency $=50 \mathrm{~Hz}$, pulse width $=3.5$ milliseconds, peak voltage
$=583$ volts) and the carcasses electrically immobilized following exsanguination. Both loins (M. longissimus lumborum; $L L$ ) from the 12 beef carcasses were hot-boned within $40 \mathrm{~min}$ post mortem. In this study, two main treatment effects i.e., AES, no additional electrical stimulation (NAES) and prerigor holding temperature $\left(\right.$ at $5{ }^{\circ} \mathrm{C}, 15^{\circ} \mathrm{C}, 25^{\circ} \mathrm{C}$, and $35^{\circ} \mathrm{C}$ for $3 \mathrm{~h}$ ) and their interactions were tested giving a total of 8 different treatment combinations (Figure 1).

Initial $\mathrm{pH}\left(\mathrm{pH}_{40 \mathrm{~min}}\right)$ was recorded and the $L L$ from either left or right (randomly selected) side of the carcass was immediately subject to low voltage electrical stimulation (AES) for $30 \mathrm{~S}$ after boning (frequency $=13.3 \mathrm{~Hz}$, pulse width $=5.4$ milliseconds, peak voltage $=104$ volts). After stimulation, $\mathrm{pH}$ was recorded once again. The $L L$ from the other side of the carcass was not additionally electrically stimulated (NAES). Immediately after stimulation or non-stimulation, approximately $10 \mathrm{~g}$ of muscle was removed, snap frozen using liquid nitrogen and stored at $-80^{\circ} \mathrm{C}$ for initial biochemical analyses. The loins were then divided into four different sub-samples, placed in plastic bags and randomly submerged in either $5^{\circ} \mathrm{C}$, $15^{\circ} \mathrm{C}, 25^{\circ} \mathrm{C}$, or $35^{\circ} \mathrm{C}$ water baths for $3 \mathrm{~h}$, which was the prerigor holding temperature. A temperature probe was inserted in to the geometric center of each loin section to monitor continuous drop in temperature (Figure 2). After $3 \mathrm{~h}$ had elapsed, the meat/muscle samples were removed from the plastic bags; their $\mathrm{pH}$ measured, and further sampled for biochemical analysis. The loin samples were transferred to the AgResearch laboratory where they were vacuum packed and aged at $10^{\circ} \mathrm{C}$ for $48 \mathrm{~h}$. After $48 \mathrm{~h}$ sampling and measurements, loins were again vacuum packed and aged at $1^{\circ} \mathrm{C}$ until 14 days post mortem.

\section{$\mathrm{pH}$}

$\mathrm{pH}$ of the LL samples was measured in duplicate by inserting a calibrated $\mathrm{pH}$ probe (Hanna HI99163 $\mathrm{pH}$ meter with a FC232D combined $\mathrm{pH} /$ temperature probe, HANNA instruments, Woonsocket, RI, USA) directly into the muscle at 40 min (before and after stimulation), $3 \mathrm{~h}, 6 \mathrm{~h}, 24 \mathrm{~h}, 48 \mathrm{~h}$, and 14 days post mortem respectively.

\section{Shear force}

The $L L$ samples were cooked in a water bath set at $99^{\circ} \mathrm{C}$ (controlled by a Digi-Sense scanning temperature logger [Eutech Instruments Pte Ltd., Singapore] with a thermocouple positioned into the center of each sample) to an internal temperature of $75^{\circ} \mathrm{C}$. After cooking, the samples were transferred to ice-water slurry for at least $10 \mathrm{~min}$. Shear force was measured by determining the force required to shear through a $10 \mathrm{~mm} \times 10 \mathrm{~mm}$ cross section sample at right angles to the fiber axis using the MIRINZ tenderometer [11]. Ten replicates were measured for each pre-cooked sample. The results were expressed as shear force $(\mathrm{kgF})$ and final values of peak 


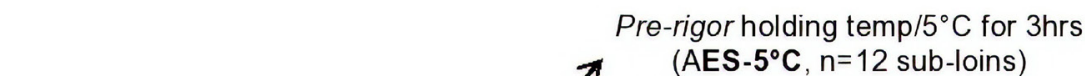

Hot boned/Additional electrical stimulation

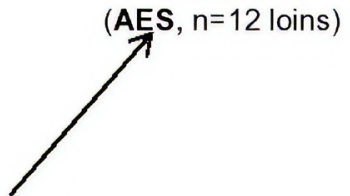

Bulls, ( $n=12$ cattle)

Electrically stunned and immobilized
(AES $-5^{\circ} \mathrm{C}, \mathrm{n}=12$ sub-loins)

Pre-rigor holding temp $/ 15^{\circ} \mathrm{C}$ for $3 \mathrm{hrs}$ (AES $-15^{\circ} \mathrm{C}, \mathrm{n}=12$ sub-loins)

Pre-rigor holding temp $/ 25^{\circ} \mathrm{C}$ for $3 \mathrm{hrs}$

(AES-25 ${ }^{\circ} \mathrm{C}, \mathrm{n}=12$ sub-loins)

Pre-rigor holding temp $/ 35^{\circ} \mathrm{C}$ for $3 \mathrm{hrs}$ (AES $-35^{\circ} \mathrm{C}, \mathrm{n}=12$ sub-loins)

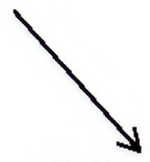

Hot boned/no additional electrical stimulation

(NAES, $\mathrm{n}=12$ loins)
Pre-rigor holding temp $/ 5^{\circ} \mathrm{C}$ for $3 \mathrm{hrs}$

(NAES- $5^{\circ} \mathrm{C}, \mathrm{n}=12$ sub-loins)

Pre-rigor holding temp $/ 15^{\circ} \mathrm{C}$ for $3 \mathrm{hrs}$

(NAES-15 ${ }^{\circ} \mathrm{C}, \mathrm{n}=12$ sub-loins)

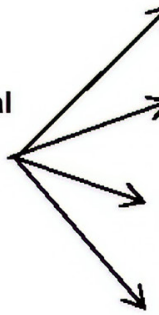

Pre-rigor holding temp $/ 25^{\circ} \mathrm{C}$ for $3 \mathrm{hrs}$

(NAES- $25^{\circ} \mathrm{C}, \mathrm{n}=12$ sub-loins)

Pre-rigor holding temp $/ 35^{\circ} \mathrm{C}$ for $3 \mathrm{hrs}$

(NAES- $35^{\circ} \mathrm{C}, \mathrm{n}=12$ sub-loins)

Figure 1. Experimental design to determine the influence of additional electrical stimulation (AES) and various pre-rigor holding temperature for $3 \mathrm{~h}$ post mortem of beef M. longissimus lumborum samples.

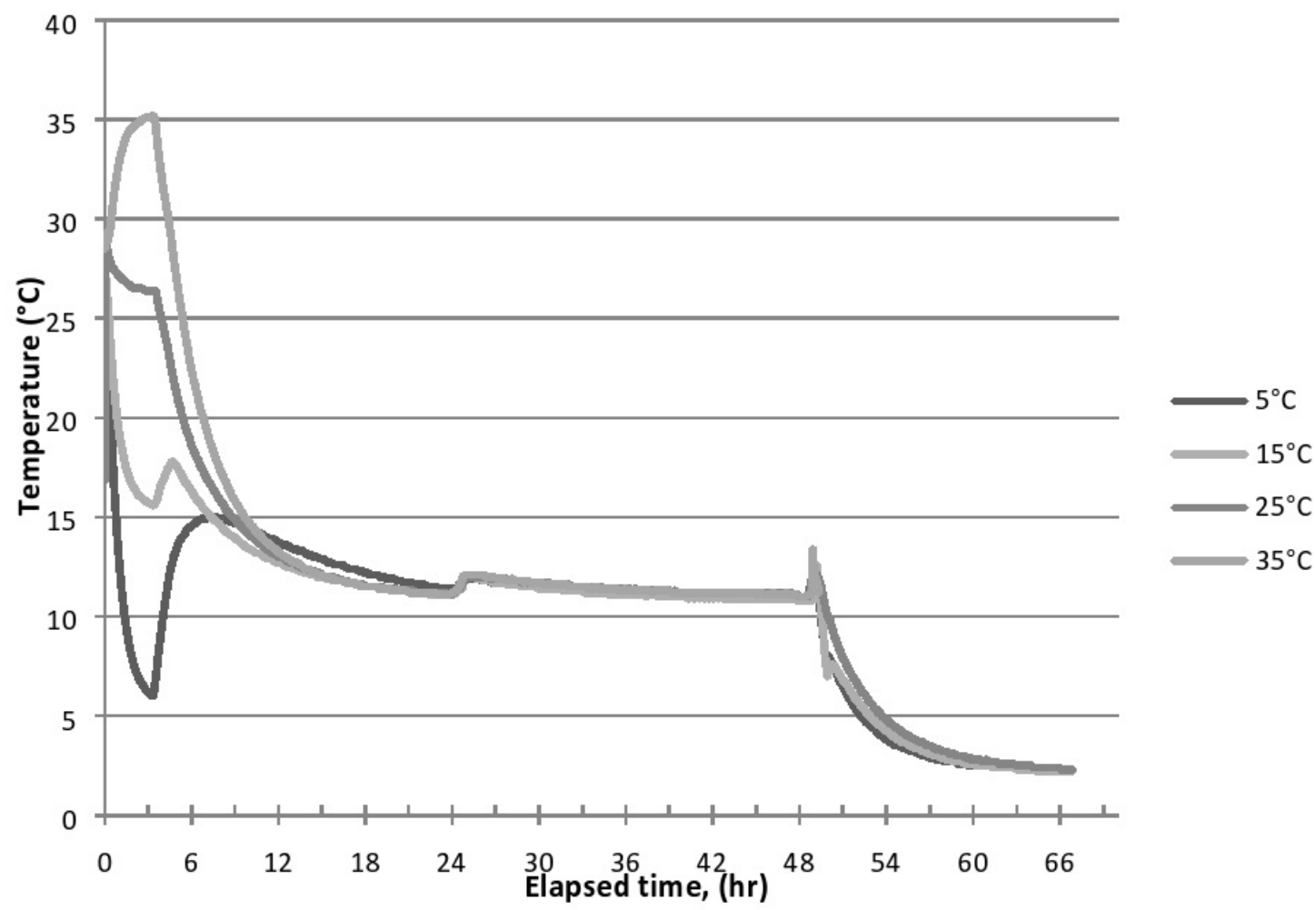

Figure 2. Temperature decline rates of the bull beef $M$. longissimus lumborum muscles assigned to additional electrical stimulation and various pre-rigor holding temperature (for $3 \mathrm{~h}$ ) methods. The samples (in plastic bag) were then placed in boxes at $10^{\circ} \mathrm{C}$ for $24 \mathrm{~h}$ post mortem. Then samples were vacuum packed and aged at $10^{\circ} \mathrm{C}$ for next $24 \mathrm{~h}$ (in total $48 \mathrm{~h}$ post mortem) and further aged at $1{ }^{\circ} \mathrm{C}$ until 14 days post mortem. 
shear force were calculated as an average from the 10 replicates.

\section{Cooking loss}

$L L$ samples were weighed before and after cooking. The cook loss was calculated as weight before cooking minus weight after cooking and expressed as a percentage of the pre-cooked weight [6].

\section{Purge and drip loss (water holding capacity)}

The $L L$ sections were weighed prior to vacuum-packaging to obtain initial weight for the purge loss measurement. After the assigned storage time, the samples were removed from the vacuum bags, patted dry on paper towels and reweighed (final weight) to determine purge loss as the difference between initial weight and final weight expressed as percentage of initial weight.

Drip loss was measured after each assigned storage (48 $\mathrm{h}$ and 14 days) following the procedure of Balan et al [12]. A sample (about $50 \mathrm{~g}$ ) of meat with any visible fat and connective tissue removed was weighed and then placed in plastic 'onion bag' netting and suspended by a hook within a closed container. After placing the container for $48 \mathrm{~h}$ at $4^{\circ} \mathrm{C}$, the sample was blotted dry and then reweighed. The drip loss was calculated as weight lost expressed as a percentage of the original sample weight.

\section{Color}

The cuts ( $48 \mathrm{~h}$ post mortem) for color measurements were placed in Cryovac food grade trays (Cryovac TQD-0900; $22.5 \mathrm{~cm} \times 17.3 \mathrm{~cm} \times 4.1 \mathrm{~cm}$; CRYOVAC, Sealed Air Corporation, Duncan, SC, USA) with the cross sectional side up and then sealed with oxygen barrier film using Cryovac LID 1050 (CRYOVAC, Sealed Air Corporation, USA) into HiOx-MAP. A high-oxygen modified atmosphere $\left(80 \% \mathrm{O}_{2} /\right.$ $20 \% \mathrm{CO}_{2}$, certified standard within $\pm 5 \%$, BOC GASES; Hamilton, New Zealand) was accomplished using a ROSS Inpack Junior A10 Packaging Machine (Ross industries packaging division, Midland, VA, USA) by applying vacuum, then flushing the package with the gas mixture and sealing. The gas mixture composition inside each pack was checked before opening with a PBI Dansensor, CheckPoint handheld gas analyzer (Ringsted, Denmark) by piercing the top layer and reading the oxygen and carbon dioxide levels. The packaged cuts were displayed for 7 days at $3^{\circ} \mathrm{C} \pm 1^{\circ} \mathrm{C}$ under continuous fluorescent natural white light $(2,800 \mathrm{~lx}$, color rendering index $=82$, color temperature $=4,000 \mathrm{~K}$; Osram, Auckland, New Zealand).

On days 1, 4, and 7 of simulated retail display under light, the cut cross sectional meat surface was measured using a Minolta Color Meter (Illuminant D65, $1 \mathrm{~cm}$ diameter aperture, $10^{\circ}$ standard observer; CR-300; Konica Minolta Photo
Imaging Inc., Tokyo, Japan) for color using the CIE $L^{*} a^{*} b^{*}$ color space. Calibration was performed by using a standard white tile prior to the color measurement. $L^{\star}$ (lightness), $a^{*}$ (redness), and $b^{*}$ (yellowness) values were used to calculate chroma $\left(\left[a^{*^{2}}+b^{* 2}\right]^{1 / 2}\right)$ and hue angle $\left(\left[b^{*} / a^{*}\right]^{\text {tan-1}}\right)[13]$. The surface meat color was scanned with the color meter covered with the same film after removing the plastic film on the top of the HiOx-MAP tray.

\section{Statistical analysis}

All statistical analysis was performed using Genstat 16th edition [14]. The $\mathrm{pH}$ fall was analyzed using analysis of variance (ANOVA) where side within animal was the blocking variable and the treatment variables were temperature, electric stimulation, time and all possible 2- and 3-way interactions. Firstly, data was analyzed excluding $\mathrm{pHu}$ using ANOVA. The shear forces, cook loss, drip and purge loss (for $48 \mathrm{~h}$ and 14 days) data were the dependent variables. For the above mentioned analysis, side within animal was included as a blocking variable and the treatment variables were temperature $\left(5^{\circ} \mathrm{C}\right.$, $15^{\circ} \mathrm{C}, 25^{\circ} \mathrm{C}$, and $35^{\circ} \mathrm{C}$ ) and additional low voltage electrical stimulation and their interaction. Then these variables were re-analyzed including $\mathrm{pHu}$ as a treatment variable, where pHu was split into three levels: low (5.4 to 5.79); intermediate (5.8 to 6.19) and high (>6.2). The initial $\mathrm{pH}$ for the animal was also included in the treatment structure. The color variables were analyzed using repeated measure ANOVA across 1,4 , and 7 days. Side within animal was included as a blocking variable and the treatments were temperature, AES, time and their 2- and 3-way interactions. Then this analysis was re-run including $\mathrm{pHu}$ (low, intermediate, and high) as a treatment and all 2-, 3-, and 4-way interactions. Least squares means for each attribute were separated using least significant differences ( $\mathrm{F}$ test, $\mathrm{p}<0.05)$.

\section{RESULTS AND DISCUSSION}

\section{Ultimate $\mathrm{pH}$ of meat samples}

In this study, out of the 12 bull carcasses used, six had high (>6.2), three intermediate (5.8 to 6.2) and three low $\mathrm{pHu}(5.4$ to 5.79) (Table 1).

\section{Temperature and $\mathrm{pH}$ decline}

AES had no effect on $\mathrm{pH}$ decline $(\mathrm{p}>0.05)$. AES did not result in an immediate fall in $\mathrm{pH}$ as expected (Table 1 ) when compared to our previous findings [6,7]. This could be due to the electrical inputs into the carcasses from head-only electrical stunning and immobilization that masked any effect of AES. Pre-rigor holding temperature (for $3 \mathrm{~h}$ ) and time-point significantly influenced $\mathrm{pH}$ fall $(\mathrm{p}<0.001)$. Generally, the highest $\mathrm{pH}$ decline was at $6 \mathrm{~h}$ post mortem except for $35^{\circ} \mathrm{C}$ samples where the highest $\mathrm{pH}$ fall was at $3 \mathrm{~h}$ post mortem. It 
Table 1. Effect of additional electrical stimulation and pre-rigor holding temperature (for $3 \mathrm{~h}$ ) on rate of $\mathrm{pH}$ fall in low, intermediate and high pHu beef $M$. longissimus lumborum samples

\begin{tabular}{|c|c|c|c|c|c|c|c|c|}
\hline \multirow{2}{*}{ Items } & \multicolumn{4}{|c|}{ AES } & \multicolumn{4}{|c|}{ NAES } \\
\hline & $5^{\circ} \mathrm{C}$ & $15^{\circ} \mathrm{C}$ & $25^{\circ} \mathrm{C}$ & $35^{\circ} \mathrm{C}$ & $5^{\circ} \mathrm{C}$ & $15^{\circ} \mathrm{C}$ & $25^{\circ} \mathrm{C}$ & $35^{\circ} \mathrm{C}$ \\
\hline \multicolumn{9}{|c|}{ Low pHu (average) } \\
\hline Before ES & 6.63 & 6.63 & 6.63 & 6.63 & 6.59 & 6.59 & 6.59 & 6.59 \\
\hline After ES & 6.46 & 6.46 & 6.46 & 6.46 & 6.59 & 6.59 & 6.59 & 6.59 \\
\hline $3 \mathrm{~h}$ & 6.41 & 6.31 & 6.13 & 5.88 & 6.46 & 6.28 & 6.15 & 6.04 \\
\hline $6 \mathrm{~h}$ & 6.19 & 6.06 & 5.8 & 5.66 & 6.17 & 6.01 & 5.87 & 5.56 \\
\hline $24 \mathrm{~h}$ & 5.67 & 5.6 & 5.64 & 5.56 & 5.64 & 5.58 & 5.61 & 5.58 \\
\hline $48 \mathrm{~h}$ & 5.61 & 5.59 & 5.6 & 5.61 & 5.59 & 5.58 & 5.62 & 5.61 \\
\hline 14 days & 5.72 & 5.72 & 5.68 & 5.69 & 5.74 & 5.69 & 5.68 & 5.70 \\
\hline \multicolumn{9}{|c|}{ Intermediate pHu (average) } \\
\hline Before ES & 6.62 & 6.62 & 6.62 & 6.62 & 6.70 & 6.70 & 6.70 & 6.70 \\
\hline After ES & 6.47 & 6.47 & 6.47 & 6.47 & 6.70 & 6.70 & 6.70 & 6.70 \\
\hline $3 \mathrm{~h}$ & 6.52 & 6.45 & 6.29 & 6.02 & 6.54 & 6.34 & 6.42 & 6.17 \\
\hline $6 \mathrm{~h}$ & 6.34 & 6.31 & 6.21 & 5.96 & 6.43 & 6.34 & 6.2 & 5.99 \\
\hline $24 \mathrm{~h}$ & 6.19 & 6.15 & 6.09 & 6.01 & 6.12 & 6.09 & 6.03 & 5.94 \\
\hline $48 \mathrm{~h}$ & 6.07 & 6.09 & 6.06 & 5.96 & 5.96 & 6.05 & 5.97 & 5.93 \\
\hline 14 days & 6.13 & 6.14 & 6.08 & 6.07 & 6.04 & 6.08 & 6.02 & 6.02 \\
\hline \multicolumn{9}{|c|}{ High pHu (average) } \\
\hline Before ES & 6.56 & 6.56 & 6.56 & 6.56 & 6.55 & 6.55 & 6.55 & 6.55 \\
\hline After ES & 6.57 & 6.57 & 6.57 & 6.57 & 6.55 & 6.55 & 6.55 & 6.55 \\
\hline $3 \mathrm{~h}$ & 6.64 & 6.48 & 6.44 & 6.38 & 6.73 & 6.50 & 6.41 & 6.35 \\
\hline $6 \mathrm{~h}$ & 6.48 & 6.40 & 6.35 & 6.36 & 6.47 & 6.49 & 6.40 & 6.35 \\
\hline $24 \mathrm{~h}$ & 6.40 & 6.49 & 6.45 & 6.42 & 6.44 & 6.32 & 6.51 & 6.39 \\
\hline $48 \mathrm{~h}$ & 6.44 & 6.48 & 6.47 & 6.42 & 6.50 & 6.36 & 6.40 & 6.41 \\
\hline 14 days & 6.52 & 6.46 & 6.46 & 6.32 & 6.49 & 6.47 & 6.37 & 6.35 \\
\hline
\end{tabular}

$n=3$ (low pHu, 5.4 to 5.79); $n=3$ (intermediate pHu, 5.8 to 6.19); $n=6$ (high pHu, >6.2).

AES, additional electrical stimulation; NAES, no additional electrical stimulation.

is well documented that high pre-rigor temperature accelerates post mortem $\mathrm{pH}$ decline $[6,7,15]$. In comparison to our previous trial in which no electrical stunning or immobilization was used [6,7], in the present study, AES-35 samples muscle $\mathrm{pH}$ (in low pHu samples, Table 1 ) declined only by $\Delta \mathrm{pH} 0.17$ $\mathrm{pH}$ units and 0.75 soon after ES and $3 \mathrm{~h}$ of holding when compared to $0.43 \mathrm{pH}$ units and 1.37 in the previous trial [6]. This loss of AES effect was due to the head-only electrical stunning and immobilization procedure carried out before AES and continued to be low when compared to rest of the samples (Table 1).

\section{Shear force}

The AES treatment applied to the hot-boned loin samples did not result in significant $(\mathrm{p}>0.05)$ changes in shear force values (Table 2). At $48 \mathrm{~h}$ post mortem, shear force values were

Table 2. Effect of additional electrical stimulation and pre-rigor holding temperature (for $3 \mathrm{~h}$ ) on shear force, cook loss and water-holding capacity of beef $M$. longissimus lumborum samples

\begin{tabular}{|c|c|c|c|c|c|c|c|c|c|c|c|c|}
\hline \multirow{2}{*}{ Items } & \multicolumn{4}{|c|}{ AES } & \multicolumn{4}{|c|}{ NAES } & \multirow{2}{*}{ SED } & \multicolumn{3}{|c|}{$p$-value } \\
\hline & $5^{\circ} \mathrm{C}$ & $15^{\circ} \mathrm{C}$ & $25^{\circ} \mathrm{C}$ & $35^{\circ} \mathrm{C}$ & $5^{\circ} \mathrm{C}$ & $15^{\circ} \mathrm{C}$ & $25^{\circ} \mathrm{C}$ & $35^{\circ} \mathrm{C}$ & & Trt & Temp & Interaction \\
\hline Shear force (kgF) $48 \mathrm{~h} \mathrm{pm}$ & 11.21 & 10.32 & 10.27 & 8.76 & 10.73 & 10.37 & 10.25 & 9.69 & 0.63 & $>0.05$ & 0.042 & $>0.05$ \\
\hline Shear force (kgF) 2 wk pm & 6.81 & 6.44 & 6.18 & 6.20 & 6.35 & 6.47 & 6.55 & 6.98 & 0.22 & $>0.05$ & $>0.05$ & $>0.05$ \\
\hline Cook loss (\%) 48 h pm & 28.20 & 22.32 & 21.08 & 23.51 & 22.13 & 23.34 & 24.28 & 23.39 & 0.89 & $>0.05$ & $>0.05$ & $>0.05$ \\
\hline Cook loss (\%) 2 wk pm & 24.93 & 22.39 & 18.68 & 22.05 & 23.07 & 23.40 & 23.71 & 23.15 & 0.69 & $>0.05$ & 0.049 & 0.009 \\
\hline Purge loss (\%) 2 wk pm & 2.03 & 1.56 & 1.37 & 2.10 & 2.20 & 1.61 & 1.67 & 2.13 & 0.17 & $>0.05$ & $>0.05$ & 0.03 \\
\hline Drip loss (\%) 48 h pm & 1.99 & 1.80 & 1.33 & 1.75 & 2.17 & 2.17 & 2.11 & 2.15 & 0.17 & 0.015 & 0.005 & 0.029 \\
\hline Drip loss (\%) 2 wk pm & 3.61 & 3.29 & 2.31 & 3.07 & 3.08 & 3.67 & 3.34 & 3.99 & 0.17 & $<0.001$ & $<0.001$ & 0.015 \\
\hline WHC (\%) 2 wk pm & 5.59 & 5.09 & 3.64 & 4.82 & 5.25 & 5.84 & 5.45 & 6.14 & 0.16 & $<0.05$ & 0.002 & 0.021 \\
\hline
\end{tabular}

AES, electrical stimulation; NAES, no additional electrical stimulation; SED, standard error of difference; WHC, water-holding capacity; 2 wk, 2 weeks; pm, post mortem ( $n=12)$. 
not significantly different for the AES samples when compared to the NAES samples (Table 2). The $3 \mathrm{~h}$ pre-rigor holding temperature had significant $(\mathrm{p}=0.042)$ effect on reducing the shear force values, where AES-35 samples had most tender meat when compared to the AES-5. For both AES and NAES shear force values decreased as the temperature increased. This decrease was greatest for the AES samples and the shear force for AES- 5 is higher than AES-35.

The trend was not observed in the shear force values at 14 days post mortem (Table 2), where there was no significant difference between the shear force values for AES and NAES samples ( $p>0.05)$. However, in high $\mathrm{pHu}$ samples the $3 \mathrm{~h}$ prerigor holding temperature had a significant effect on the shear force values recorded at $48 \mathrm{~h}$ post mortem $(\mathrm{p}=0.046)$. AES35 samples had the least shear force values (less than $7 \mathrm{kgF}$ ), when compared to the AES-5. At 14 days post mortem, there was no significant difference for the shear force values among the three $\mathrm{pHu}$ categories due to the additional stimulation and $3 \mathrm{~h}$ pre-rigor holding temperature. Interestingly, at $48 \mathrm{~h}$ post mortem when compared to low and high $\mathrm{pHu}$ samples, most of the intermediate $\mathrm{pHu}$ samples (both AES and NAES) had higher shear force values (Taking $11 \mathrm{kgF}$ as the upper limit for acceptable cooked meat tenderness [16]). However, after 14 days of ageing this observed effect was lost as all the samples (intermediate $\mathrm{pHu}$ ) were tender (less than $7.5 \mathrm{kgF}$ ) except the ES-35 samples which was $\sim 8.8 \mathrm{kgF}$. This observation supports previous findings, that the increased toughness of meat with a ultimate $\mathrm{pH}$ between 5.8 to 6.19 is due to slow rate of tenderization $[4,17]$.

Earlier findings have suggested that pre-rigor temperature had the most dominant effect on the shear force values [18]. It was found that samples held at $38^{\circ} \mathrm{C}$ had significantly higher shear force values when compared to $15^{\circ} \mathrm{C}$ samples. However, in this study the effect was evident only in the intermediate pHu beef samples (Figure 3a, 3b). The difference in the findings of the two studies may be due to the long storage at high temperature $\left(38^{\circ} \mathrm{C}\right)$ by Kim et al [18] that would have caused the protein to denature. However, in the present study the samples were held at $35^{\circ} \mathrm{C}$ only for $3 \mathrm{~h}$ in pre-rigor compared to the $24 \mathrm{~h}$ at $38^{\circ} \mathrm{C}$ in the former study.

\section{Cook loss}

At the sampling points of $48 \mathrm{~h}$ and 14 days post mortem, there was a significant interaction $(\mathrm{p}<0.01)$ effect of AES and prerigor holding temperature on cook loss for the AES and NAES (Table 2). Previous findings have shown that cooking loss was not affected by ES [6,7]. Among the AES samples, the cook loss was greatest for AES-5 and lowest for AES-25. The cook loss was significantly higher for AES- 5 when compared to at all the other pre-rigor holding temperatures $(\mathrm{p}<$ $0.05)[6,7]$. Contrary to our results, earlier findings have shown that higher pre-rigor temperature results in higher cook loss [19]. The difference between the findings of the two studies may be due to the long storage at different temperature $\left(15^{\circ} \mathrm{C}\right.$ or $\left.35^{\circ} \mathrm{C}\right)$ until rigor. Generally cooking loss was lowest for the high $\mathrm{pHu}$ groups at both time points $(\mathrm{p}$ $=0.008$ and 0.055 for $48 \mathrm{~h}$ and 14 days post mortem respectively) (Figure 4a, 4b).

\section{Purge loss}

The influence of AES on purge loss was dependent on prerigor holding temperature (Table 2; $\mathrm{p}=0.03$ ). Previous findings have shown that ES had no effect on purge loss [18]. Among, the AES samples, AES-25 had significantly lower purge than AES-5. However, in NAES samples there was no significant ( $p>0.05$ ) difference in the purge loss for the different temperatures. Purge loss was significantly influenced by $\mathrm{pHu}$ (Figure 5; $\mathrm{p}<0.05$ ). Generally, the purge loss was greater for the low $\mathrm{pHu}$ group than for the high $\mathrm{pHu}$ group. Interestingly, for the low pHu group (among the AES samples) the purge loss was least for $25^{\circ} \mathrm{C}$ than $5^{\circ} \mathrm{C}$ and $15^{\circ} \mathrm{C}$ and among NAES samples, purge loss was highest for $35^{\circ} \mathrm{C}$ than for $5^{\circ} \mathrm{C}$ and there was no difference for the intermediate and high pHu groups [18].

\section{Drip loss}

AES had no effect on drip loss at $48 \mathrm{~h}$ post mortem (Table 2; $\mathrm{p}>0.05$ ), but the $3 \mathrm{~h}$ pre-rigor holding temperature did. For both AES and NAES samples, drip loss was higher for $5^{\circ} \mathrm{C}$ and $35^{\circ} \mathrm{C}$ and lower for $15^{\circ} \mathrm{C}$ and $25^{\circ} \mathrm{C}$. Our findings are somewhat similar to the earlier findings [18], which reported that drip loss was higher for the meat held at $38^{\circ} \mathrm{C}$ pre-rigor when compared to the $15^{\circ} \mathrm{C}$ beef samples. After 14 days of ageing, (Table 2) drip loss was significantly influenced by AES, pre-rigor holding temperature and their interaction effect $(\mathrm{p}=0.029)$. These results are contradictory to the earlier finding [18], which reported that additional stimulation did not influence the drip loss values. The difference between the current findings and the previous findings may be due to different pre-rigor conditions.

For NAES samples there was no significant difference in drip loss between the various pre-rigor holding temperatures. Among AES samples, the samples held at $25^{\circ} \mathrm{C}$ for $3 \mathrm{~h}$ had the lowest drip loss compared to the others $(\mathrm{p}<0.05)$. At rigor and during the early post rigor period, the drip loss value of AES-15 samples was lower compared to AES-35 samples. However, as the ageing (14 days post mortem) progressed the drip loss values of the AES-15 samples increased to greater than AES-35 [20].

Drip loss was significantly influenced by pHu (Figure 6a, $6 \mathrm{~b} ; \mathrm{p}<0.001)$. In the intermediate and high $\mathrm{pHu}$ groups there was no significant difference in the drip loss for the various pre-rigor holding temperatures. Whereas for the low $\mathrm{pHu}$ samples, the drip loss for $15^{\circ} \mathrm{C}$ and $25^{\circ} \mathrm{C}$ is lower than for $5^{\circ} \mathrm{C}$ 

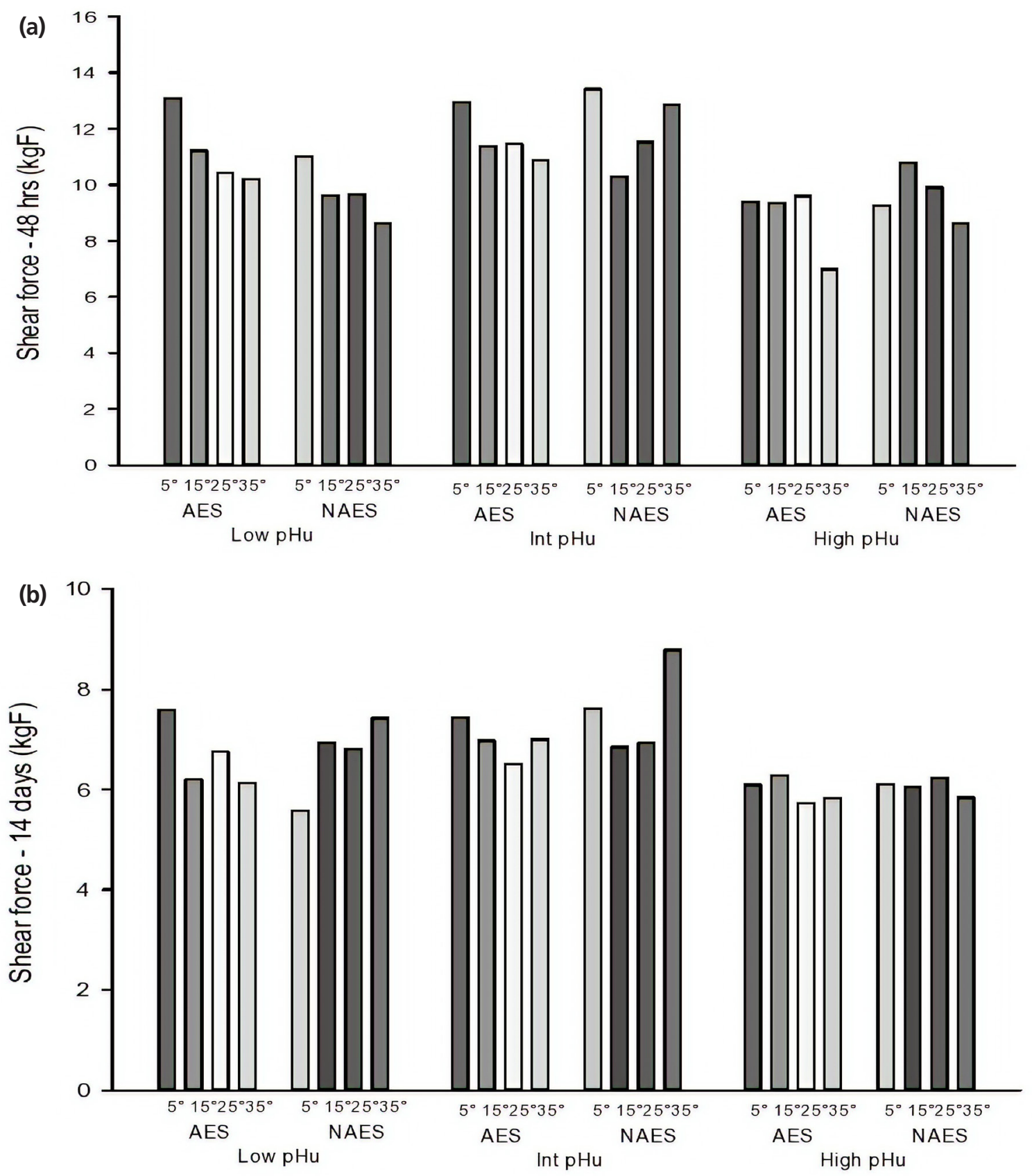

Figure 3. (a) Effect of AES and various pre-rigor holding temperature (for $3 \mathrm{~h}$ ) methods on shear force (48 h post mortem) of low, intermediate and high pHu beef $M$. longissimus lumborum samples. AES, additional electrical stimulation; NAES, no additional electrical stimulation. Low pHu $(n=3)$, Int (intermediate) pHu $(n=3)$, and high pHu $(n=6)$. Treatment effect [AES vs ES] ( $p>0.05)$; $p H$ effect $(p>0.05)$; temperature effect $(p=0.046)$; interaction effect $(p>0.05$, standard error of difference [SED] = 1.76). (b) Effect of AES and various pre-rigor holding temperature (for $3 \mathrm{~h}$ ) methods on shear force (14 days post mortem) of low, intermediate and high pHu beef samples. Low pHu $(n=3)$, Int (intermediate) pHu $(n=3)$, and high pHu $(n=6)$. Treatment effect [AES vs ES] ( $p>0.05)$; pH effect ( $p>0.05)$; temperature effect $(p>0.05)$; interaction effect $(p>0.05$, SED $=0.63)$

and $35^{\circ} \mathrm{C}$. It is well documented that the formation of drip is thought to be as a result of shrinkage of the myofibrils due to the $\mathrm{pH}$ fall post mortem and the denaturation of protein such as myosin, which occurs when a low $\mathrm{pH}$ and a high pre-rigor temperature environment is created [21]. In this study, based on the $\mathrm{pH}$ (Table 1) and temperature (Figure 2) data, AES-35 reached low value of $\mathrm{pH}(<5.9)$, whereas the sample tem- perature was maintained at $35^{\circ} \mathrm{C}$ for $3 \mathrm{~h}$. The $\mathrm{pH}$ decline after death was much slower in AES-25 and AES-15 samples. The observed $\mathrm{pH}$ and pre-rigor holding temperature conditions in the AES-35 are severe enough to cause the excess drip loss. Interestingly, after 14 days of ageing, drip loss was significantly influenced by $\mathrm{AES}, \mathrm{pHu}$, pre-rigor holding temperature and their interaction effect $(\mathrm{p}<0.05)$ 

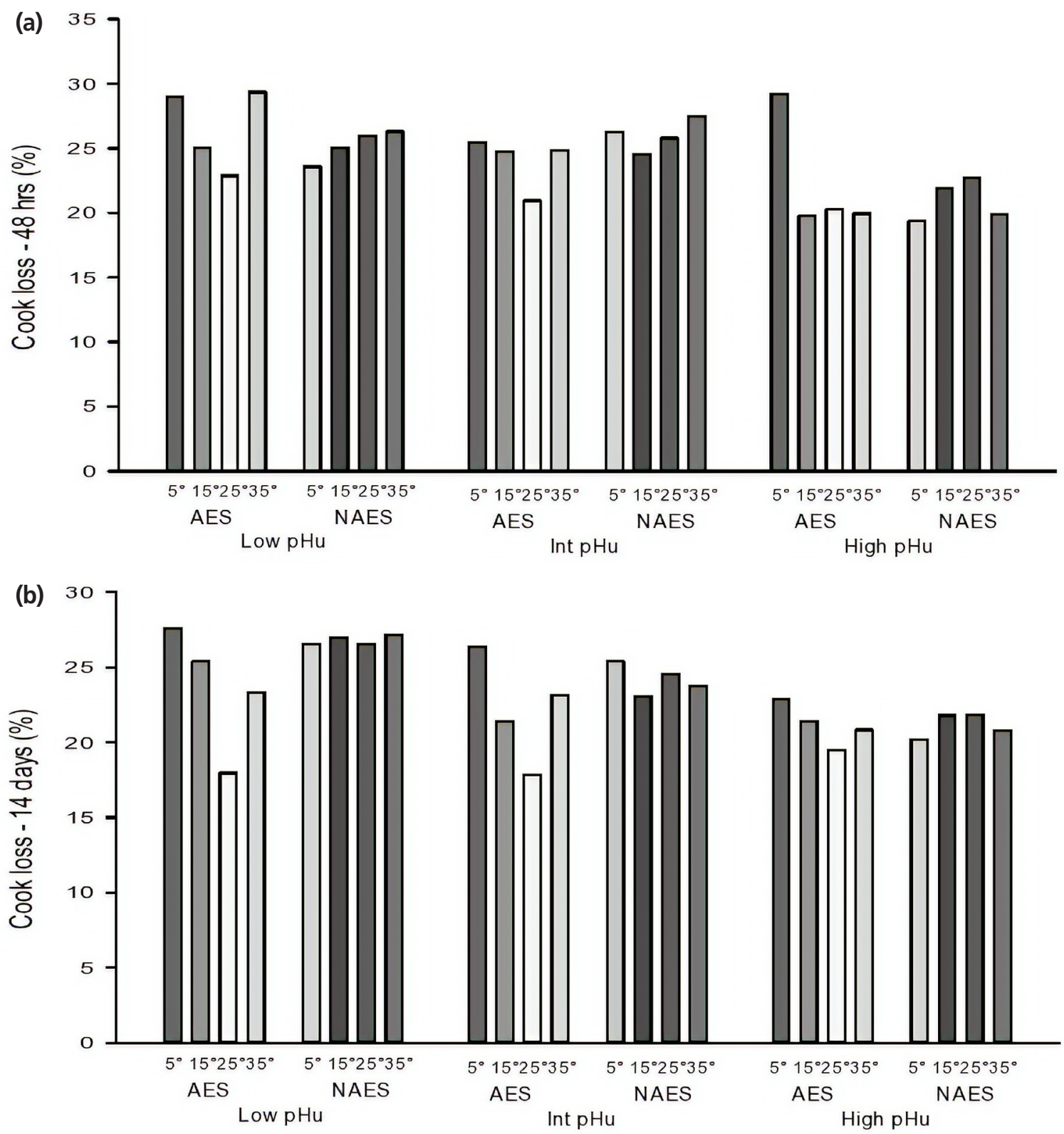

Figure 4. (a) Effect of AES and various pre-rigor holding temperature (for $3 \mathrm{~h}$ ) methods on cook loss ( $48 \mathrm{~h}$ post mortem) of low, intermediate and high pHu beef $M$. longissimus lumborum samples. AES, additional electrical stimulation; NAES, no additional electrical stimulation. Low pHu $(n=3)$, Int (intermediate) pHu ( $n=3)$, and high pHu $(n=6)$. Treatment effect [AES vs ES] ( $p>0.05)$; $\mathrm{pH}$ effect $(p=0.008)$; temperature effect $(p=0.039)$; Interaction effect (stimulation $\times$ temperature) $(p<0.001$, standard error of difference $[S E D]=1.79$ ). (b) Effect of AES and various pre-rigor holding temperature (for $3 \mathrm{~h}$ ) methods on cook loss (14 days post mortem) of low, intermediate and high pHu beef samples. Low pHu $(n=3)$, Int (intermediate) pHu $(n=3)$, and high pHu $(n=6)$. Treatment effect [AES vs ES] ( $p>0.05)$; $p H$ effect $(p=0.05)$; temperature effect ( $p>0.05)$; Interaction effect (stimulation xtemperature) $(p=0.015$, SED $=1.87)$.

(Figure 6b). However, for AES samples, there was significantly higher drip loss observed at $5^{\circ} \mathrm{C}$ than at $25^{\circ} \mathrm{C}$ in the low pHu group only. As expected, drip loss was greatest in low $\mathrm{pHu}$ group when compared to other pHu groups. However, the AES-25 treatment of the low pHu group had almost similar drip loss values to other samples from high and intermediate $\mathrm{pHu}$ groups. This observation requires further investigation to validate the finding in order to establish whether it is a feasible method of reducing drip loss in low
$\mathrm{pHu}$ beef. It was proposed that there was a clear relationship between drip loss and shear force values $\left(r^{2}=0.70\right)$ which was observed in this study [20].

\section{Water holding capacity}

The water holding capacity (WHC \% loss) data presented in this study is defined as the sum of the purge and the drip loss values, where lower values denote higher WHC and vice versa. The interaction between AES and pre-rigor holding 


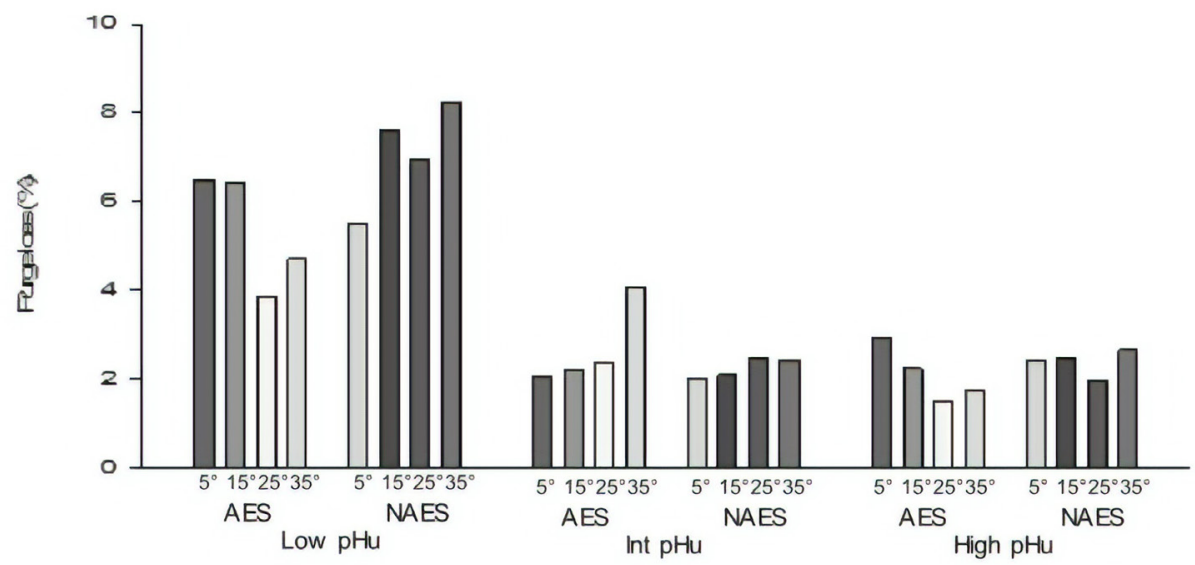

Figure 5. Effect of AES and various pre-rigor holding temperature (for $3 \mathrm{~h}$ ) methods on purge loss (14 days post mortem) of low, intermediate and high pHu beef $M$. longissimus lumborum samples. AES, additional electrical stimulation; NAES, no additional electrical stimulation. Low pHu $(n=3)$, Int (intermediate) pHu ( $n=3)$, and high pHu $(n=6)$. Treatment effect [AES vs ES] ( $p>0.05)$; $p H$ effect $(p<0.001)$; temperature effect $(p=0.014)$; interaction effect (stimulation $\times$ temperature) $(p=0.006)$; (pH xtemperature) $(p=0.011)$; (stimulation $\times$ temperature $\times \mathrm{pH})(p=0.002$, standard error of difference $=0.63)$.
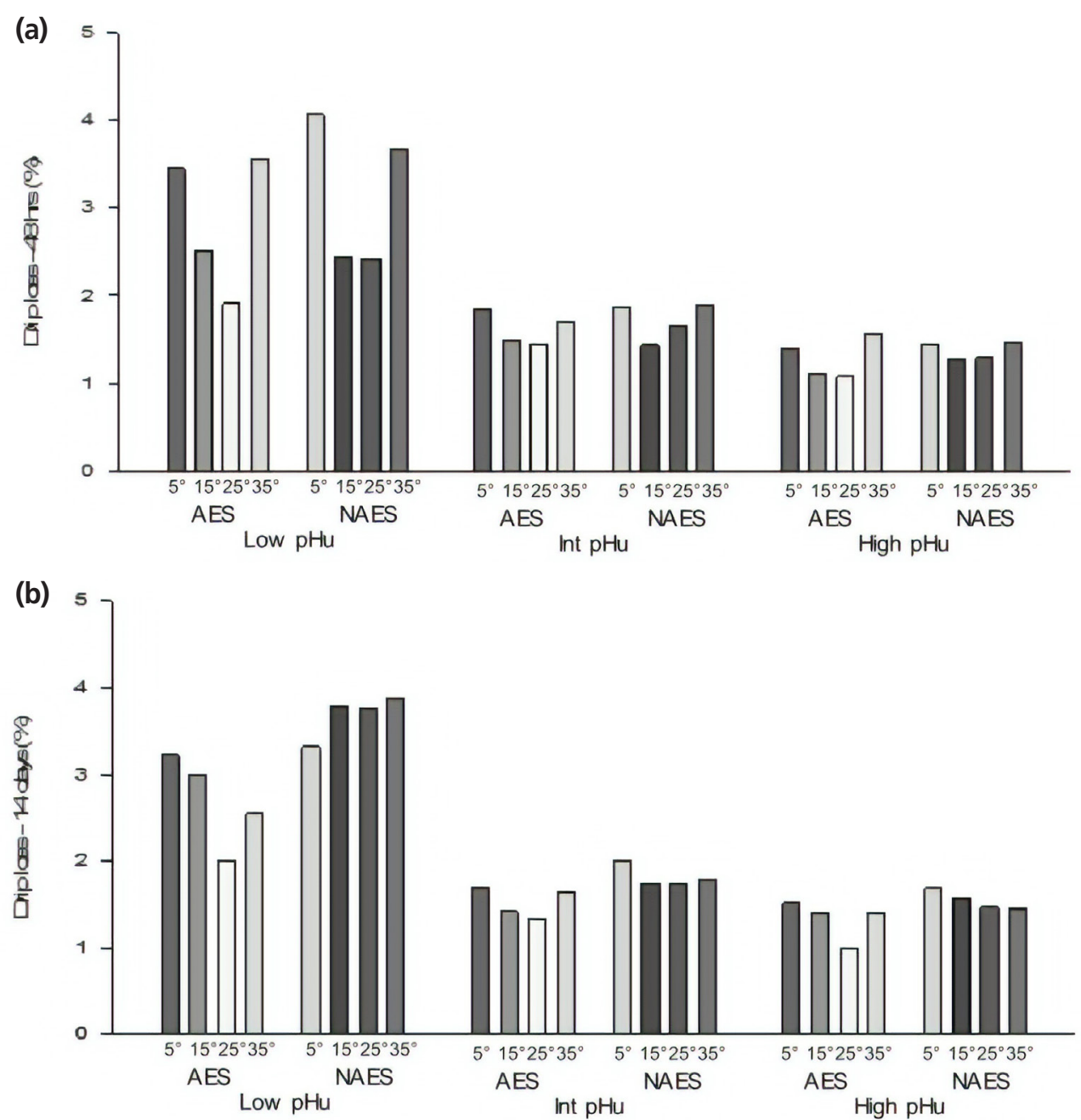

Figure 6. (a) Effect of AES and various pre-rigor holding temperature (for $3 \mathrm{~h}$ ) methods on drip loss (48 h post mortem) of low, intermediate and high pHu beef $M$. longissimus lumborum samples. AES, additional electrical stimulation; NAES, no additional electrical stimulation. Low pHu $(n=3)$, Int (intermediate) pHu $(n=3)$, and high pHu $(n=6)$. Treatment effect [AES vs ES] ( $p>0.05)$; $p H$ effect $(p<0.001)$; temperature effect $(p<0.001)$; interaction effect ( $p H \times$ temperature) $(p=0.015$, standard error of difference $[S E D]=0.17$ ). (b) Effect of AES and various pre-rigor holding temperature (for $3 \mathrm{~h}$ ) methods on drip loss (14 days post mortem) of low, intermediate and high pHu beef samples. Low pHu $(n=3)$, Int (intermediate) pHu $(n=3)$, and high pHu $(n=6)$. Treatment effect [AES vs ES] $(p<0.008)$; $p H$ effect $(p<0.001)$; temperature effect $(p=0.003)$; interaction effect (stimulation xtemperature) $(p=0.015)$; (stimulation $\times$ temperaturexpH) $(p=0.036, S E D=0.27)$. 
temperature applied to the hot-boned loin samples significantly influenced the WHC (Table 2; $\mathrm{p}=0.009$ ) as was previously reported [18]. A significant increase in WHC was observed for AES-25 when compared to the NAES-25 treatment. There was no significant difference in WHC between NAES samples due to the various pre-rigor holding temperatures, whereas there was significant difference between AES-25 compared to AES-5. WHC was significantly influenced by $\mathrm{pHu}(\mathrm{p}<$ $0.05)$. Among the three $\mathrm{pHu}$ groups, the low $\mathrm{pHu}$ treatment had the least WHC for each pre-rigor holding temperature (Figure 7). By contrast, in the AES treatments, there was significantly less WHC for AES-5 and AES-15 for the low $\mathrm{pHu}$ treatment when compared to high and intermediate $\mathrm{pHu}$ treatments. As expected, the low $\mathrm{pHu}$ samples (AES25 and AES-35) had significantly lower WHC when compared to high $\mathrm{pHu}$ samples at the same temperatures.

Among the NAES samples, there was no significant difference between the various pre-rigor holding temperatures for each of the pHu samples. However, AES (in high and low but not in intermediate $\mathrm{pHu}$ ) significantly increased the WHC for AES- 25 when compared to AES- 5 treatments. These findings contradicted earlier findings [22], which reported low $\mathrm{pH}$ and high temperature condition in post mortem muscle reduced WHC due to the denaturation of muscle proteins such as myosin. In the current study, AES and suitable prerigor holding temperature such as AES- 25 based can override the negative effects of ES [20].

\section{Color stability}

There are inconsistent reports in the literature on the effects of ES on color stability. Some studies found no color difference due to ES treatment [23,24]. In general, it is documented that ES significantly improves lean color appearance, possibly by ensuring more complete post mortem glycolysis within $24 \mathrm{~h}[25,26]$. Overall, the AES applied to the hot-boned loin samples did not influence $(\mathrm{p}>0.05)$ color stability (Table 3; $\mathrm{p}>0.05$ ).

The various pre-rigor holding temperatures and time (display days) did influence $(\mathrm{p}<0.05)$ color stability but no significant difference was found due to AES ( $\mathrm{p}>0.05$ ). When compared to AES-5, AES-35 samples had significantly lower $L^{*}$ values (indicator of lightness) regardless of time (display days) or stimulation and AES-35 samples had the least $L^{\star}$ values at day 1 and 4. Farouk and Swan [27], found $24 \mathrm{~h}$ post mortem samples held at $35^{\circ} \mathrm{C}$ had significantly higher $L^{*}$ values when compared to $5^{\circ} \mathrm{C}$ samples and it was suggested that high rigor temperature caused protein denaturation. In this study, samples were exposed to high pre-rigor temperature only for $3 \mathrm{~h}$. The values of red ( $a^{*}$ values), yellow $\left(b^{*}\right)$ color, hue angle (indication of discoloration) and chroma (indication of saturation of color or vividness) values decreased as display days increased. The values were significantly lower on day 7 when

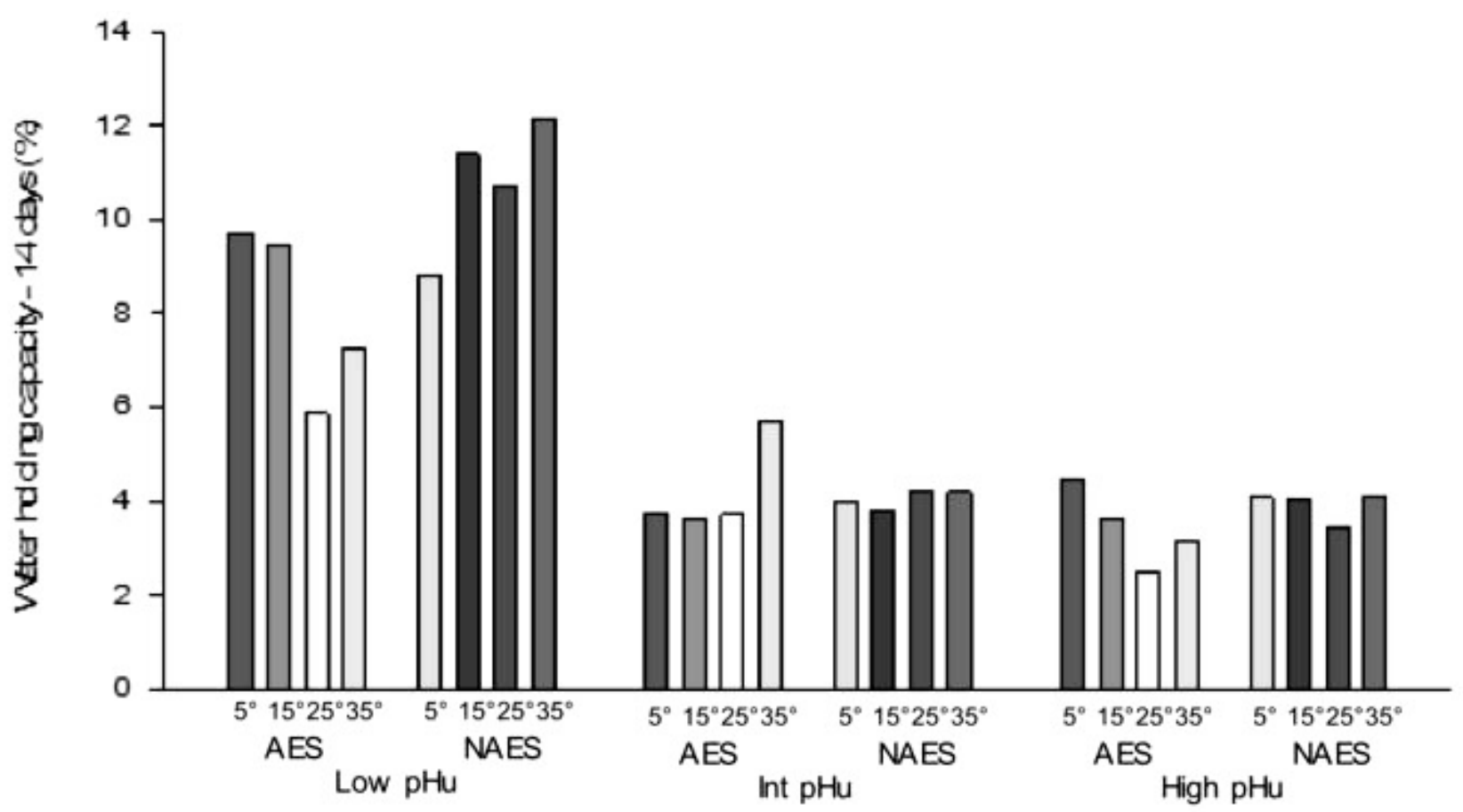

Figure 7. Effect of AES and various pre-rigor holding temperature (for $3 \mathrm{~h}$ ) methods on water holding capacity (\% loss) (14 days post mortem) of low, intermediate and high pHu beef $M$. longissimus lumborum samples. AES, additional electrical stimulation; NAES, no additional electrical stimulation. Low pHu ( $n=3)$, Int (intermediate) pHu $(n=3)$, and high pHu $(n=6)$. Treatment effect [AES vs ES] ( $p=0.02)$; $\mathrm{pH}$ effect $(p<0.05)$; temperature effect $(p=0.001)$; interaction effect (stimulation $\times$ temperature) ( $p=$ $0.002) ;$ (stimulation $\times$ temperature $\mathrm{pH})(\mathrm{p}=0.021$, standard error of difference $=0.16)$. 
Table 3. Effect of AES and various pre-rigor holding temperature (for $3 \mathrm{~h}$ ) methods on the color stability ( $48 \mathrm{~h}$ post mortem) of beef $\mathrm{M}$. longissimus lumborum samples

\begin{tabular}{|c|c|c|c|c|c|c|c|c|c|c|c|c|c|}
\hline \multirow{2}{*}{ Items } & \multicolumn{4}{|c|}{ AES } & \multicolumn{4}{|c|}{ NAES } & \multirow{2}{*}{ SED } & \multicolumn{4}{|c|}{ p-value } \\
\hline & $5^{\circ} \mathrm{C}$ & $15^{\circ} \mathrm{C}$ & $25^{\circ} \mathrm{C}$ & $35^{\circ} \mathrm{C}$ & $5^{\circ} \mathrm{C}$ & $15^{\circ} \mathrm{C}$ & $25^{\circ} \mathrm{C}$ & $35^{\circ} \mathrm{C}$ & & Trt & Temp & Day & Interaction \\
\hline \multicolumn{14}{|l|}{$L^{*}$ value } \\
\hline day 1 & 41.54 & 40.75 & 41.08 & 40.19 & 41.60 & 41.76 & 40.91 & 40.16 & 0.407 & $>0.05$ & $<0.001$ & $<0.001$ & $>0.05$ \\
\hline day 4 & 41.43 & 40.80 & 40.68 & 40.45 & 41.21 & 41.22 & 40.72 & 40.11 & & & & & \\
\hline day 7 & 40.89 & 40.43 & 40.50 & 39.53 & 40.29 & 40.33 & 40.41 & 40.08 & & & & & \\
\hline \multicolumn{14}{|l|}{$a^{*}$ value } \\
\hline day 1 & 19.59 & 20.51 & 19.50 & 19.86 & 20.02 & 20.22 & 19.91 & 19.31 & 0.530 & $>0.05$ & 0.017 & $<0.001$ & $>0.05$ \\
\hline day 4 & 17.71 & 18.25 & 17.51 & 16.49 & 17.57 & 17.96 & 17.20 & 16.87 & & & & & \\
\hline day 7 & 16.51 & 16.52 & 15.98 & 16.08 & 16.53 & 16.63 & 16.14 & 15.27 & & & & & \\
\hline \multicolumn{14}{|l|}{$b^{*}$ value } \\
\hline day 1 & 7.01 & 7.57 & 6.92 & 7.05 & 7.22 & 7.41 & 7.01 & 6.71 & 0.279 & $>0.05$ & 0.008 & $<0.001$ & $>0.05$ \\
\hline day 4 & 6.01 & 6.20 & 5.77 & 5.30 & 5.90 & 6.09 & 5.58 & 5.46 & & & & & \\
\hline day 7 & 5.39 & 5.31 & 5.04 & 5.16 & 5.37 & 5.36 & 5.15 & 4.75 & & & & & \\
\hline \multicolumn{14}{|c|}{ Hue angle } \\
\hline day 1 & 19.70 & 20.21 & 19.50 & 19.54 & 19.82 & 20.11 & 19.42 & 19.13 & 0.401 & $>0.05$ & 0.006 & $<0.001$ & $>0.05$ \\
\hline day 4 & 18.68 & 18.70 & 18.19 & 17.69 & 18.44 & 18.64 & 17.96 & 17.80 & & & & & \\
\hline day 7 & 17.97 & 17.72 & 17.39 & 17.67 & 17.92 & 17.87 & 17.59 & 17.08 & & & & & \\
\hline \multicolumn{14}{|c|}{ Chroma value } \\
\hline day 1 & 20.81 & 21.87 & 20.70 & 21.08 & 21.29 & 21.54 & 21.11 & 20.44 & 0.585 & $>0.05$ & 0.014 & $<0.001$ & $>0.05$ \\
\hline day 4 & 18.72 & 19.29 & 18.44 & 17.32 & 18.54 & 18.98 & 18.09 & 17.74 & & & & & \\
\hline day 7 & 17.38 & 17.36 & 16.77 & 16.89 & 17.39 & 17.48 & 16.95 & 16.01 & & & & & \\
\hline
\end{tabular}

AES, electrical stimulation; NAES, no additional electrical stimulation; SED, standard error of difference; Trt, treatment effect [AES vs NAES], $n=12$.

compared to day 1 . Our results are contradictory to the recent findings of Kim et al [15], who reported that hot-boned beef loins within 30 min post mortem kept in a $38^{\circ} \mathrm{C}$ water bath during the pre-rigor seemed to have greater $L^{*}, a^{*}$, hue and chroma angle values at 1 day post mortem compared with the loins held at $15^{\circ} \mathrm{C}$, regardless of ES of the beef carcass. The discrepancy between the two studies may have been due to the long storage at high temperature $\left(\right.$ at $38^{\circ} \mathrm{C}$ ) until rigor in their studies which had resulted in the protein denaturation and myofibrillar lattice shrinkage [24,28].

For $a^{*}$ and $b^{*}$ values, there was a significant interaction effect between display day and $\mathrm{pHu}$ group (Table 4 ). For $a^{*}$ there was also a significant interaction effect between $3 \mathrm{~h}$ prerigor holding temperature and $\mathrm{pHu}$ group. Among the low and intermediate $\mathrm{pHu}$ groups, day $1 a^{*}$ values were the highest when compared to days 4 and 7. In the high pHu group, there was no significant difference due to the duration of display, except for the observation that samples held at $35^{\circ} \mathrm{C}$ for $3 \mathrm{~h}$ pre-rigor had a lower $a^{*}$ values for day 4 and 7 when compared to day 1 . Similarly, day 4 samples that were held at high pre-rigor temperature (i.e. $35^{\circ} \mathrm{C}$ ) had lower $a^{*}$ values when compared to other pre-rigor temperature treatments. There was a significant interaction effect between display day and $\mathrm{pHu}$ interaction on Hue angle. For chroma angle, the display day and pre-rigor temperatures are influenced by the pHu group (Table 4).

\section{CONCLUSION}

The results from the current study demonstrate that AES applied, after electrical stunning and Halal slaughter did not influence the various meat quality parameters of bull beef $M$. longissimus lumborum except the drip loss (only at 14 days of ageing). However, the pre-rigor holding temperature (i.e. $25^{\circ} \mathrm{C}$ ) alone or in combination with AES resulted in more tender meat, less cook loss, decreased purge and drip loss and increased WHC in bull beef samples.

\section{CONFLICT OF INTEREST}

We certify that there is no conflict of interest with any financial organization regarding the material discussed in the manuscript. Farouk MM, Staincliffe M, Stuart AD, Kemp R, Craigie $\mathrm{C}$ are employees of AgResearch Ltd.

\section{ACKNOWLEDGMENTS}

This study was supported by the AGMARDT Postdoctoral fellowship fund (A19076). The authors would like to acknowledge to Pete Dobbie, Sorivan Chem-Kieth, Kevin Taukiri, and Carolijn van der Stok (Food Assurance and Meat Quality team at AgResearch) and Suchitra Prabhu for assistance in sample and data collection. 
Table 4. Effect of AES and various pre-rigor holding temperature (for $3 \mathrm{~h}$ ) methods on the lightness, redness and yellowness (48 h post mortem) of low, intermediate and high $\mathrm{pHu}$ beef $M$. longissimus lumborum samples

\begin{tabular}{|c|c|c|c|c|c|c|c|c|c|}
\hline \multirow{2}{*}{ Items } & & \multicolumn{4}{|c|}{ AES } & \multicolumn{4}{|c|}{ NAES } \\
\hline & & $5^{\circ} \mathrm{C}$ & $15^{\circ} \mathrm{C}$ & $25^{\circ} \mathrm{C}$ & $35^{\circ} \mathrm{C}$ & $5^{\circ} \mathrm{C}$ & $15^{\circ} \mathrm{C}$ & $25^{\circ} \mathrm{C}$ & $35^{\circ} \mathrm{C}$ \\
\hline \multicolumn{10}{|l|}{$L^{*}$ value } \\
\hline \multirow[t]{3}{*}{ Low pHu } & Day 1 & 43.18 & 42.35 & 42.80 & 42.00 & 43.33 & 42.87 & 42.11 & 41.85 \\
\hline & Day 4 & 43.06 & 42.67 & 42.05 & 42.61 & 42.97 & 42.66 & 42.64 & 41.90 \\
\hline & Day 7 & 42.16 & 41.90 & 42.61 & 42.14 & 42.26 & 41.89 & 41.86 & 41.87 \\
\hline \multirow[t]{3}{*}{ Intermediate pHu } & Day 1 & 42.03 & 41.02 & 42.25 & 40.63 & 42.41 & 42.59 & 41.56 & 41.04 \\
\hline & Day 4 & 42.45 & 41.14 & 42.08 & 39.90 & 41.79 & 42.65 & 40.36 & 38.97 \\
\hline & Day 7 & 40.51 & 41.02 & 41.22 & 39.32 & 40.08 & 40.83 & 40.70 & 39.52 \\
\hline \multirow[t]{3}{*}{ High pHu } & Day 1 & 40.57 & 39.87 & 39.83 & 39.15 & 40.46 & 40.94 & 40.10 & 39.03 \\
\hline & Day 4 & 40.29 & 39.76 & 39.53 & 39.55 & 40.14 & 40.02 & 39.89 & 39.60 \\
\hline & Day 7 & 40.39 & 39.50 & 39.20 & 38.29 & 39.38 & 39.39 & 39.59 & 39.38 \\
\hline \multicolumn{10}{|l|}{$a^{*}$ value } \\
\hline \multirow[t]{3}{*}{ Low pHu } & Day 1 & 19.36 & 21.86 & 21.41 & 21.3 & 21.09 & 21.19 & 20.45 & 21.42 \\
\hline & Day 4 & 16.61 & 18.47 & 17.93 & 18.7 & 17.03 & 18.23 & 16.68 & 18.97 \\
\hline & Day 7 & 16.22 & 17.62 & 16.47 & 17.9 & 16.5 & 16.44 & 16.06 & 17.5 \\
\hline \multirow[t]{3}{*}{ Intermediate pHu } & Day 1 & 20.84 & 21.55 & 20.36 & 20.7 & 21.52 & 20.57 & 21.73 & 19.38 \\
\hline & Day 4 & 18.67 & 18.83 & 17.99 & 17.1 & 18.75 & 18.34 & 18.72 & 17.11 \\
\hline & Day 7 & 17.52 & 17.47 & 16.03 & 16.9 & 17.56 & 16.72 & 17.36 & 15.26 \\
\hline \multirow[t]{3}{*}{ High pHu } & Day 1 & 19.3 & 19.5 & 18.26 & 18.9 & 18.98 & 19.63 & 19.04 & 18.23 \\
\hline & Day 4 & 17.95 & 17.95 & 17.14 & 15.2 & 17.44 & 17.71 & 16.96 & 15.73 \\
\hline & Day 7 & 16.32 & 15.65 & 15.72 & 14.9 & 16.2 & 16.69 & 15.78 & 14.17 \\
\hline \multicolumn{10}{|l|}{$b^{*}$ value } \\
\hline \multirow[t]{3}{*}{ Low pHu } & Day 1 & 6.84 & 8.3 & 8.05 & 7.81 & 7.57 & 7.86 & 7.23 & 7.84 \\
\hline & Day 4 & 5.85 & 6.76 & 6.37 & 6.52 & 5.87 & 6.6 & 5.6 & 6.89 \\
\hline & Day 7 & 5.78 & 6.36 & 5.89 & 6.35 & 5.73 & 5.7 & 5.49 & 6.28 \\
\hline \multirow[t]{3}{*}{ Intermediate $\mathrm{pHu}$} & Day 1 & 7.74 & 8.15 & 7.27 & 7.43 & 8.03 & 7.37 & 7.59 & 6.65 \\
\hline & Day 4 & 6.58 & 6.5 & 6.01 & 5.58 & 6.46 & 6.11 & 6.34 & 5.46 \\
\hline & Day 7 & 5.94 & 5.66 & 4.92 & 5.51 & 5.76 & 5.16 & 5.67 & 4.67 \\
\hline \multirow[t]{3}{*}{ High pHu } & Day 1 & 6.86 & 7.02 & 6.24 & 6.55 & 6.78 & 7.2 & 6.71 & 6.17 \\
\hline & Day 4 & 5.91 & 5.82 & 5.39 & 4.6 & 5.74 & 5.83 & 5.32 & 4.75 \\
\hline & Day 7 & 5.01 & 4.66 & 4.65 & 4.45 & 5.07 & 5.26 & 4.8 & 4.01 \\
\hline \multicolumn{10}{|l|}{ Hue angle } \\
\hline \multirow[t]{3}{*}{ Low pHu } & Day 1 & 19.51 & 20.80 & 20.63 & 20.20 & 19.75 & 20.32 & 19.52 & 20.17 \\
\hline & Day 4 & 19.2 & 20.02 & 19.51 & 19.27 & 18.92 & 19.85 & 18.62 & 20.03 \\
\hline & Day 7 & 19.42 & 19.88 & 19.51 & 19.56 & 19.08 & 19.13 & 18.77 & 19.8 \\
\hline \multirow[t]{3}{*}{ Intermediate pHu } & Day 1 & 20.41 & 20.71 & 19.7 & 19.76 & 20.5 & 19.75 & 19.31 & 18.96 \\
\hline & Day 4 & 19.36 & 19.04 & 18.48 & 18.04 & 19.01 & 18.31 & 18.72 & 17.69 \\
\hline & Day 7 & 18.73 & 17.94 & 16.98 & 18.1 & 18.14 & 17.12 & 18.09 & 17.01 \\
\hline High pHu & Day 1 & 19.56 & 19.74 & 18.86 & 19.13 & 19.62 & 20.13 & 19.41 & 18.66 \\
\hline & Day 4 & 18.19 & 17.93 & 17.44 & 16.78 & 18.02 & 18.15 & 17.38 & 16.73 \\
\hline & Day 7 & 16.99 & 16.56 & 16.47 & 16.58 & 17.26 & 17.48 & 16.83 & 15.73 \\
\hline Chroma value & & & & & & & & & \\
\hline Low pHu & Day 1 & 20.53 & 23.39 & 22.88 & 22.68 & 22.42 & 22.61 & 21.69 & 22.82 \\
\hline & Day 4 & 17.63 & 19.69 & 19.05 & 19.79 & 18.03 & 19.4 & 17.59 & 20.19 \\
\hline & Day 7 & 17.24 & 18.74 & 17.51 & 19.01 & 17.48 & 17.41 & 16.99 & 18.6 \\
\hline Intermediate $\mathrm{pHu}$ & Day 1 & 22.23 & 23.04 & 21.62 & 22.02 & 22.98 & 21.85 & 23.02 & 20.49 \\
\hline & Day 4 & 19.8 & 19.92 & 18.96 & 18.02 & 19.83 & 19.34 & 19.76 & 17.96 \\
\hline & Day 7 & 18.5 & 18.36 & 16.76 & 17.74 & 18.48 & 17.5 & 18.26 & 15.96 \\
\hline High pHu & Day 1 & 20.48 & 20.72 & 19.3 & 19.97 & 20.16 & 20.91 & 20.18 & 19.24 \\
\hline & Day 4 & 18.9 & 18.88 & 17.97 & 15.86 & 18.37 & 18.65 & 17.77 & 16.44 \\
\hline & Day 7 & 17.08 & 16.33 & 16.39 & 15.55 & 16.97 & 17.5 & 16.5 & 14.73 \\
\hline
\end{tabular}

AES, additional electrical stimulation; NAES, no additional electrical stimulation.

Low pHu $(\mathrm{n}=3)$, Int (intermediate) $\mathrm{pHu}(\mathrm{n}=3)$, and high $\mathrm{pHu}(\mathrm{n}=6)$.

$L^{*}=$ Treatment effect [AES vs NAES] $(p>0.05) ; \mathrm{pH}$ effect $(p>0.05)$; temperature effect $(\boldsymbol{p}<0.001)$; day effect $(p<0.001)$; interaction effect $($ stimulation $\times$ temperature) $(p>0.05)$; $(p H \times$ temperature) $(p>0.05) ;(p H \times$ day $)(p>0.05$, SED $=1.79)$.

$a^{*}=$ treatment effect [AES vs NAES] ( $\left.p>0.05\right)$; $\mathrm{pH}$ effect $(p=0.004)$; temperature effect $(p=0.006)$; day effect $(p<0.001)$; interaction effect $($ stimulation $\times$ temperature) ( $p>0.05)$; $(p H \times$ temperature) $(\mathrm{p}=0.005) ;(\mathrm{pH} \times$ day) $(\mathrm{p}=0.004, \mathrm{SED}=1.16)$.

$b^{*}=$ treatment effect [AES vS NAES] $(p>0.05) ; \mathrm{pH}$ effect $(p=0.022)$; temperature effect $(p=0.003)$; day effect $(p<0.001)$; interaction effect $($ stimulation $\times$ temperature $)(p>0.05)$; $(p H \times$ temperature) $(\mathbf{p}=0.017) ;(\mathrm{pH} \times$ day) $(\mathrm{p}>0.05$, SED $=0.63)$.

Hue angle = treatment effect [AES vS ES] ( $p>0.05)$; $\mathrm{pH}$ effect $(p>0.05)$; temperature effect $(p=0.005)$; day effect $(p<0.001)$; interaction effect $(s t i m u l a t i o n \times$ temperature) $(p>0.05) ;(p H \times$ temperature) $(p>0.05) ;(p H \times$ day $)(p=0.001, S E D=1.28)$.

Chroma value $=$ treatment effect [AES vs NAES] $(p>0.05)$; $p$ H effect $(p=0.023)$; temperature effect $(p>0.05)$; day effect $(p<0.001)$; interaction effect $($ stimulation $\times$ pH) $(p=0.005) ;($ stimula-

tion $\times$ temperature) $(\mathrm{p}>0.05) ;(\mathrm{pH} \times$ temperature $)(\mathrm{p}=\mathbf{0 . 0 0 6}) ;(\mathrm{pH} \times$ day $)(\mathrm{p}=\mathbf{0 . 0 1 4}, \mathrm{SED}=1.25)$. 


\section{REFERENCES}

1. Red Meat Sector Strategy Report. Beef + Lamb New Zealand Limited. Meat Industry Association of New Zealand [Internet]. MIA; 2011. Annual Report [cited 2019 Oct 1]. Available from: https://www.mia.co.nz/assets/MIA-Publications/Red-MeatSector-Strategy-Report-May-2011.pdf

2. Lomiwes D, Farouk MM, Frost DA, Dobbie PM, Young OA. Small heat shock proteins and toughness in intermediate $\mathrm{pH}_{\mathrm{u}}$ beef. Meat Sci 2013;95:472-9. https://doi.org/10.1016/j. meatsci.2013.05.022

3. Silva JA, Patarata L, Martins C. Influence of ultimate $\mathrm{pH}$ on bovine meat tenderness during ageing. Meat Sci 1999;52:4539. https://doi.org/10.1016/S0309-1740(99)00029-7

4. Lomiwes D, Farouk MM, Wu G, Young OA. The development of meat tenderness is likely to be compartmentalised by ultimate $\mathrm{pH}$. Meat Sci 2014;96:646-51. https://doi.org/ 10.1016/j.meatsci.2013.08.022

5. Adeyemi KD, Sazili AQ. Efficacy of carcass electrical stimulation in meat quality enhancement: a review. Asian-Australas J Anim Sci 2014;27:447-56. https://doi.org/10.5713/ajas.2013. 13463

6. Balan P, Farouk MM, Stuart AD, et al. Effects of electrical stimulation and pre-rigor conditioning temperature on aging potential of hot-boned beef $M$. longissimus lumborum. Anim Sci J 2019;90:1050-1059. https://doi.org/10.1111/asj.13217

7. Balan P, Kim YHB, Stuart A, Kemp R, Farouk MM. Effects of electrical stimulation and pre-rigor conditioning temperature on ageing potential of hot-boned beef muscle. Arch Latinoam Prod Anim 2014;22:490-3.

8. Kim YHB, Lonergan SM, Grubbs JK, et al. Effect of low voltage electrical stimulation on protein and quality changes in bovine muscles during postmortem aging. Meat Sci 2013;94:28996. https://doi.org/10.1016/j.meatsci.2013.02.013

9. Simmons NJ, Daly CC, Cummings TL, Morgan SK, Johnson NV, Lombard A. Reassessing the principles of electrical stimulation. Meat Sci 2008;80:110-22. https://doi.org/10.1016/j. meatsci.2008.05.006

10. Marsh BB, Ringkob TP, Russell RL, Swartz DR, Pagel LA. Effects of early-postmortem glycolytic rate on beef tenderness. Meat Sci 1987;21:241-8. https://doi.org/10.1016/0309-1740 (87)90061-1

11. Chrystall BB, Devine CE. Quality assurance for tenderness. Hamilton, New Zealand: MIRINZ Publication; 1991. Report No.: 872.

12. Balan P, Kim YHB, Stuart AD, et al. Effect of fast freezing then thaw-aging on meat quality attributes of lamb $M$. longissimus lumborum. Anim Sci J 2019;90:1060-9. https://doi.org/10. 1111/asj.13216

13.AMSA. Guidelines for meat color evaluation. In: Proceedings Proceedings of the 44th Annual Reciprocal Meat Conference 1991; Manhattan, KS, USA. p. 1-17.
14. GenStat. GenStat for Windows, Version 12.2.0.3717. 12th ed. Oxford, UK: VSN International; 2010.

15. Kim YHB, Warner RD, Rosenvold K. Influence of high prerigor temperature and fast $\mathrm{pH}$ fall on muscle proteins and meat quality: a review. Anim Prod Sci 2014;54:375-95. https:// doi.org/10.1071/AN13329

16. Bickerstaffe R, Bekhit AED, Robertson LJ, Roberts N, Geesink $\mathrm{GH}$. Impact of introducing specifications on the tenderness of retail meat. Meat Sci 2001;59:303-15. https://doi.org/10. 1016/S0309-1740(01)00083-3

17. Balan P, Kim YHB, Blijenburg R. Small heat shock protein degradation could be an indicator of the extent of myofibrillar protein degradation. Meat Sci 2014;97:220-2. https://doi.org/ 10.1016/j.meatsci.2014.01.019

18. Kim YHB, Stuart A, Nygaard G, Rosenvold K. High pre rigor temperature limits the ageing potential of beef that is not completely overcome by electrical stimulation and muscle restraining. Meat Sci 2012;91:62-8. https://doi.org/10.1016/ j.meatsci.2011.12.007

19. Devine CE, Payne SR, Peachey BM, Lowe TE, Ingram JR, Cook CJ. High and low rigor temperature effects on sheep meat tenderness and ageing. Meat Sci 2002;60:141-6. https://doi. org/10.1016/S0309-1740(01)00115-2

20. Rosenvold K, North M, Devine C, et al. The protective effect of electrical stimulation and wrapping on beef tenderness at high pre rigor temperatures. Meat Sci 2008;79:299-306. https:// doi.org/10.1016/j.meatsci.2007.10.002

21.den Hertog-Meischke MJA, Smulders FJM, Van Logtestijn JG, van Knapen F. The effect of electrical stimulation on the water-holding, capacity and protein denaturation of two bovine muscles. J Anim Sci 1997;75:118-24. https://doi.org/ $10.2527 / 1997.751118 \mathrm{x}$

22. Offer G. Modelling of the formation of pale, soft and exudative meat: effects of chilling regime and rate and extent of glycolysis. Meat Sci 1991;30:157-84. https://doi.org/10.1016/0309-1740 (91) $90005-\mathrm{B}$

23. McKenna DR, Maddock TD, Savell JW. Water-holding and color characteristics of beef from electrically stimulated carcasses. J Muscle Foods 2003;14:33-43. https://doi.org/10.1111/ j.1745-4573.2003.tb00344.x

24. Strydom PE, Frylinck L, Smith MF. Should electrical stimulation be applied when cold shortening is not a risk? Meat Sci 2005;70:733-42. https://doi.org/10.1016/j.meatsci.2005.03. 010

25. Aalhus JL, Jones SDM, Best DR, Robertson WM, Lutz S. The efficacy of high and low voltage electrical stimulation under different chilling regimes. Can J Anim Sci 1994;74:433-42. https://doi.org/10.4141/cjas94-062

26.Smith GC. Effects of electrical stimulation on meat quality, color, grade, heat ring and palatability. In: Pearson AM, Dutson TR, editors. Advances in meat research: electrical stimulation. Westport. CT, USA: AVI Publishing Company Inc; 1985. 
p. 121-58.

27. Farouk MM, Swan JE. Effect of rigor temperature and frozen storage on functional properties of hot-boned manufacturing beef. Meat Sci 1998;49:233-47. https://doi.org/10.1016/S0309-
1740(97)00134-4

28. Offer G, Trinick J. On the mechanism of water holding in meat: the swelling and shrinking of myofibrils. Meat Sci 1983;8: 245-81. 